\title{
Does insertion and use of an intrauterine device increase the risk of pelvic inflammatory disease among women with sexually transmitted infection? A systematic review
}

\author{
Anshu P. Mohllajee ${ }^{\mathrm{a}}$, Kathryn M. Curtis ${ }^{\mathrm{a}, *}$, Herbert B. Peterson ${ }^{\text {b,c }}$ \\ ${ }^{a}$ Division of Reproductive Health, WHO Collaborating Center in Reproductive Health, Centers for Disease Control and Prevention, Atlanta, GA 30341, USA \\ ${ }^{\mathrm{b}}$ Department of Maternal and Child Health, School of Public Health, University of North Carolina at Chapel Hill, Chapel Hill, NC 27599, USA \\ ${ }^{\mathrm{c} D e p a r t m e n t ~ o f ~ O b s t e t r i c s}$ and Gynecology, School of Medicine, University of North Carolina at Chapel Hill, Chapel Hill, NC 27599, USA \\ Received 27 July 2005; accepted 11 August 2005
}

\begin{abstract}
Concerns exist as to whether the insertion of copper and levonorgestrel-releasing intrauterine devices (IUDs) increases the risk of pelvic inflammatory disease (PID) among women with sexually transmitted infection (STI). We searched the MEDLINE database for all articles published between January 1966 and March 2005 that included evidence relevant to IUDs and STIs and PID. None of the studies that examined women with STIs compared the risk of PID between those with insertion or use of an IUD and those who had not received an IUD. We reviewed indirect evidence from six prospective studies that examined women with insertion of a copper IUD and compared risk of PID between those with STIs at the time of insertion with those with no STIs. These studies suggested that women with chlamydial infection or gonorrhea at the time of IUD insertion were at an increased risk of PID relative to women without infection. The absolute risk of PID was low for both groups $(0-5 \%$ for those with STIs and $0-2 \%$ for those without).
\end{abstract}

(C) 2006 Elsevier Inc. All rights reserved.

Keywords: Intrauterine device; Sexually transmitted infection; Pelvic inflammatory disease; Systematic review

\section{Introduction}

Approximately 160 million women worldwide use intrauterine devices (IUDs), making the IUD the most popular contraceptive method after sterilization [1]. IUDs are safe and highly effective, long-acting methods of contraception. Theoretical concerns exist, however, as to whether women who have sexually transmitted infections (STIs) and who are therefore at risk of developing pelvic inflammatory disease (PID) further increase their risk of PID with the insertion and use of IUDs. The majority of cases of PID are caused by sexually transmitted microorganisms, with endogenous flora of the lower genital tract playing a lesser role [2]. It is hypothesized that when an IUD is inserted, sexually transmitted microorganisms that may be present in the endocervical canal could be transported to the uterine cavity [3].

* Corresponding reviewer. Tel.: +1 770488 6397; fax: +1 7704886391.

E-mail address: kmc6@cdc.gov (K.M. Curtis).
We conducted this systematic review in preparation for an Expert Working Group of international family planning experts convened by the World Health Organization (WHO) in October 2003 to develop and revise medical eligibility criteria for contraceptive use. In this report, we describe the evidence obtained through our systematic review regarding whether insertion and use of a copper or levonorgestrelreleasing IUD increases the risk of PID among women with STIs; we also provide the WHO recommendations that were derived in part from this evidence.

\section{Materials and methods}

We searched the MEDLINE database for all articles (in all languages) published in peer-reviewed journals between January 1966 and March 2005, for evidence relevant to the insertion and use of copper and levonorgestrel-releasing intrauterine devices and STIs and PID. The following search strategy was used: [mirena.mp. or levonorgestrel.mp. and (exp intrauterine devices/ or (iud or iucd or ius).mp. or (intrauterine adj3 system).mp. or (intra-uterine adj3 sys- 
tem).mp. or (intrauterine adj3 device).mp. or (intra-uterine adj3 device).mp.) or exp intrauterine devices/ or (iud or iucd or ius).mp. or (intrauterine adj3 system).mp. or (intra-uterine adj3 system).mp. or (intrauterine adj3 device).mp. or (intrauterine adj3 device).mp.] AND [(sexually transmitted infection\$ or sti or stis or sexually transmitted disease\$ or std\$).mp. or gonorrhea/ or gonorrhea.mp. or exp chlamydiales/ or chlamydiales.mp. or chlamydiaceae.mp. or chlamydia.mp. or chlamydia muridarum.mp. or chlamydia trachomatis.mp. or chlamydiaceae infections/ or exp chlamydia infections/ or chlamydiaceae infection\$.mp. or chlamydia infection\$.mp.].

We searched reference lists from articles identified by the search, as well as key review articles, to identify additional articles. We did not try to identify unpublished articles or abstracts from scientific conferences. In an attempt to locate additional articles, we contacted an expert in the field but did not learn of any other published literature.

\subsection{Selection of studies}

The search strategy identified a total of 365 articles that considered IUDs as well as STIs and PID. Our primary goal was to identify studies that examined whether, among women with STIs, the insertion and use of copper or levonorgestrel-releasing IUDs increased the risk of PID over that of non-IUD users. After reviewing the titles and abstracts of these articles as well as the full article when necessary, we did not identify any studies that met these criteria. When we looked for indirect evidence that could help us assess our study question, we identified six studies that examined women who received a copper IUD and assessed whether women with STIs at the time the device was inserted had a greater risk of PID than women without STIs at the time of insertion [4-9]. We contacted one author to clarify whether screening for STI occurred before or after insertion in the author's study. We did not identify any direct or indirect evidence that examined the use of levonorgestrelreleasing IUDs among women with STIs and risk of PID.

\subsection{Assessment of the study quality and synthesis of the data}

We summarized and systematically assessed the evidence through the use of standard abstract forms [10]. We assessed the quality of each individual piece of evidence using a preliminary draft of the Grades of Recommendation Assessment, Development and Evaluation (GRADE) system (Appendix A) [11].

Because six studies reported percentages of women with STIs and PID, crude relative risks were calculated from the study reports for this systematic review (Table 1). We assessed heterogeneity by examining the characteristics of the participants included in each study. We did not calculate a summary statistic for PID because of the heterogeneity of the studies, but summary graphs of the relative risks are included in this review (Figs. 1 and 2). We have also included evidence that summarizes the studies reviewed (Table 2).

\section{Results}

We did not identify any studies that examined whether copper or levonorgestrel-releasing IUD insertion or use modified the risk of PID among women with STIs, i.e., studies that examined a group of women with current STIs and compared the risk of PID in women who had an IUD inserted with women who did not undergo IUD insertion. We did not identify any studies regarding levonorgestrelreleasing IUDs either.

In the absence of direct evidence, we identified six studies that provided indirect evidence, i.e., they examined whether women who had an STI at the time of copper IUD insertion were at a greater risk of developing PID than women without an STI at the time of IUD insertion (Table 1) [4-9]. These studies varied substantially in their design and methodology. Three were prospective studies whose primary goal was to evaluate screening for STIs prior to IUD

Table 1

Women who developed pelvic inflammatory disease following IUD insertion

\begin{tabular}{|c|c|c|c|c|}
\hline \multirow[t]{2}{*}{ Author, year } & \multirow[t]{2}{*}{ Country } & \multirow[t]{2}{*}{ Follow-up } & \multicolumn{2}{|c|}{ Women who developed PID following IUD insertion, $\%(n)$} \\
\hline & & & STI present at insertion & No STI present at insertion \\
\hline Sinei et al., $1990[6]$ & Kenya & 1 month & $4.3 \%(5)$ of 117 women $^{\mathrm{a}}$ & $1.3 \%$ (9) of 670 women \\
\hline Sinei et al., 1990 [6] & Kenya & 1 month & $3.0 \%(7)$ of 232 women $^{\mathrm{b}}$ & $1.1 \%(15)$ of 1339 women \\
\hline Pap-Akeson et al., 1992 [8] & Sweden & 2 years & $0 \%(0)$ of 13 women & $2.1 \%(9)$ of 432 women \\
\hline Walsh et al., 1994 [9] & USA (LA) & 3 months & $0 \%(0)$ of 7 women & $0.5 \%(2)$ of 435 women \\
\hline Skjeldestad et al., 1996 [7] & Norway & 3 months & $0 \%(0)$ of 5 women & $0 \%(0)$ of 952 women \\
\hline Faúndes et al., 1998 [4] & Brazil & 1 month & $5.2 \%$ (1) of 19 women & $0 \%(0)$ of 308 women \\
\hline Faúndes et al., 1998 [4] & Brazil & 1 month & $10.5 \%$ (2) of 19 women $^{\mathrm{c}}$ & $0 \%(0)$ of 308 women \\
\hline Morrison et al., ${ }^{\mathrm{d}} 1999$ [5] & Kenya & 4 months & $3.1 \%(1)$ of 32 women & $0.4 \%(2)$ of 548 women \\
\hline
\end{tabular}

Adapted from: Best K. IUD not recommended for increased STD risk. Network 2000;20:12-5.

a Placebo group only.

${ }^{b}$ Combining the placebo and antibiotic groups (there were no treatment effects).

${ }^{c}$ Includes one woman suspected of having PID (not diagnosed).

d Cervical swabs taken 1 month after insertion of IUD. 


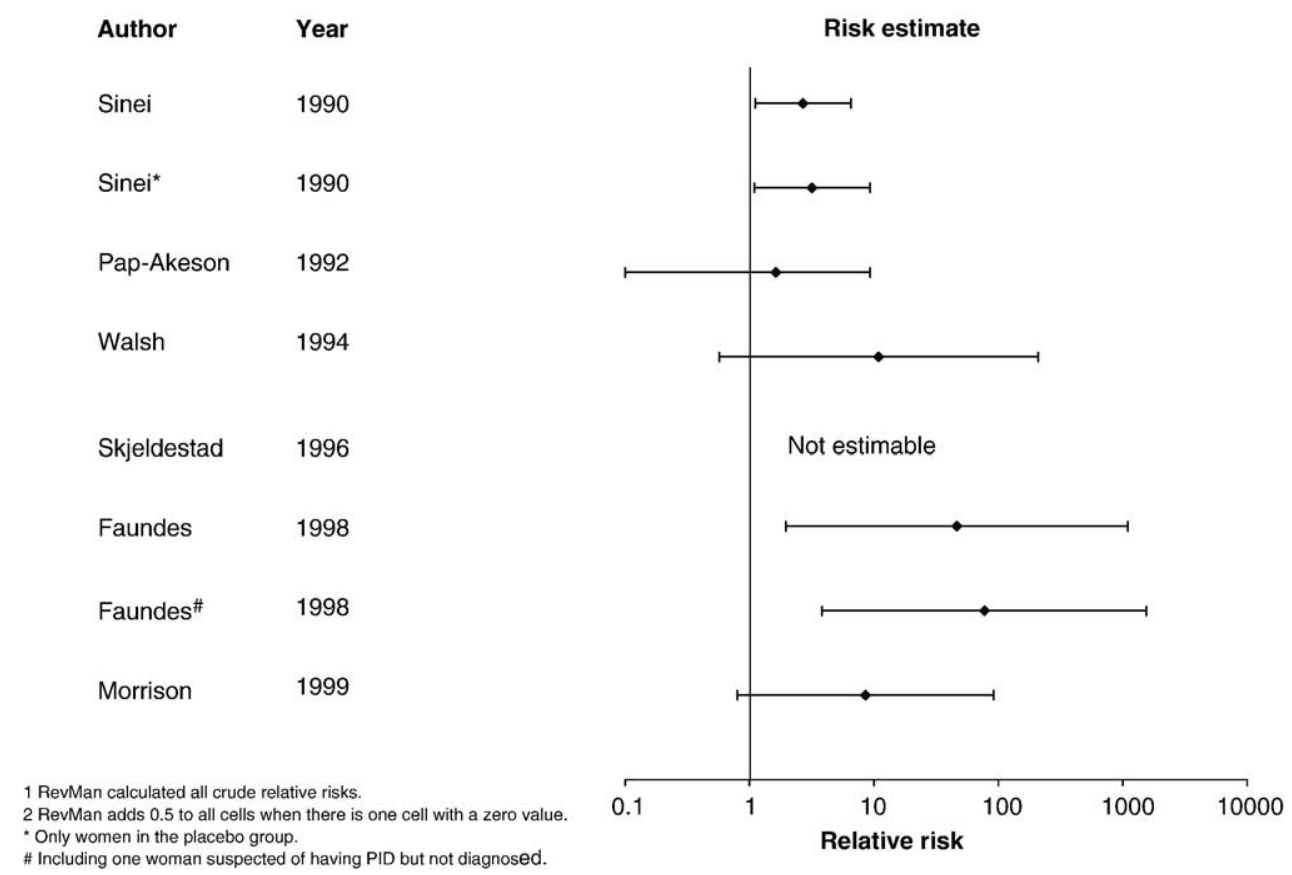

Fig. 1. Crude relative risk of PID among women with and without STI at insertion [1,2].

insertion $[4,5,7]$. The three others were randomized controlled trials evaluating either the use of antibiotics or the placement of strings of the IUD as approaches to decrease PID among women receiving the device; for our purposes, however, we considered these to be prospective observational studies, as we used the presence of an STI at time of IUD insertion as the "exposure" and development of PID as the outcome $[6,8,9]$. All six studies reported rates of PID following IUD insertion; three of the studies did not provide or describe diagnostic criteria for PID [4,7,8]. The degree of screening for STI risk to determine eligibility for inserting an IUD differed among studies, with four studies using some type of syndromic screening [4-6,8]; two of these studies also used behavioral risk assessment [4,5]. Two of the six studies did not report details of their criteria for screening and exclusion [7,9]. Three studies tested for cervical chlamydial infection only $[4,7,8]$, and the rest for both chlamydial infection and gonorrhea $[5,6,9]$. In four of the studies, results of STI testing were obtained after insertion $[4,6-8]$; in one, laboratory results were obtained

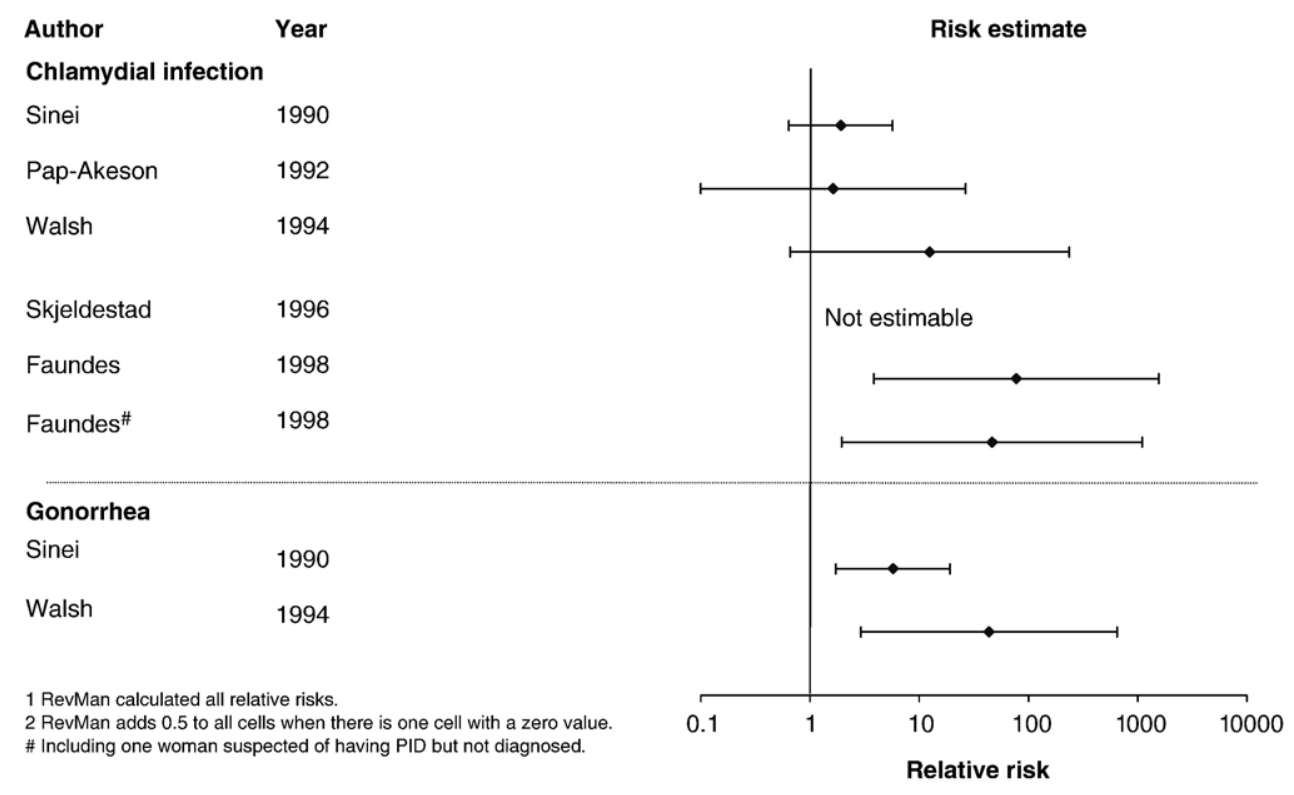

Fig. 2. Crude relative risk of PID among women with and without chlamydial infection or gonorrhea at insertion $[1,2]$. 
Table 2

Evidence table summarizing risk for PID among women who have a current STI at IUD insertion

\begin{tabular}{|c|c|c|c|c|c|c|c|c|}
\hline Author, year, support & Objective & Study Design & Population & $\begin{array}{l}\text { Outcome (and } \\
\text { assessment) }\end{array}$ & Screening & Results & Weaknesses & Quality \\
\hline $\begin{array}{l}\text { Sinei et al., } \\
1990 \text { [6], } \\
\text { FHI, USAID }\end{array}$ & $\begin{array}{l}\text { To determine the effectiveness } \\
\text { of } 200 \mathrm{mg} \text { of doxycycline } \\
\text { given orally at the time of } \\
\text { insertion in reducing the } \\
\text { occurrence of PID }\end{array}$ & $\begin{array}{l}\text { Double-blind RCT } \\
\text { for } 1 \text { month; } \\
\text { Kenya 1984-1986 }\end{array}$ & $\begin{array}{l}1813 \text { prospective } \\
\text { IUD users; } 904 \text { in } \\
\text { doxycycline group } \\
\text { and } 909 \text { in placebo } \\
\text { group } \\
\text { At follow-up: } \\
1655 \text { women; } \\
827 \text { doxycycline, } \\
828 \text { placebo }\end{array}$ & $\begin{array}{l}\text { PID: defined by } \\
\text { the Infectious } \\
\text { Disease Society } \\
\text { of Obstetrics and } \\
\text { Gynecology in the } \\
\text { United States }\end{array}$ & $\begin{array}{l}\text { - Women with an } \\
\text { active PID were } \\
\text { excluded from the } \\
\text { study. There is no } \\
\text { other information } \\
\text { about screening based } \\
\text { on signs and } \\
\text { symptoms of } \\
\text { chlamydial infection } \\
\text { or gonorrhea } \\
\text { - Samples were taken } \\
\text { before insertion, but } \\
\text { results were obtained } \\
\text { after insertion } \\
\text { Screening results: } \\
-11 / 1582(0.66 \%) \\
\text { women positive for } \\
\text { both chlamydial } \\
\text { infection and } \\
\text { gonorrhea at insertion } \\
-46 / 1582(2.8 \%) \\
\text { women with gonorrhea } \\
\text { only at insertion } \\
-186 / 1582(11.2 \%) \\
\text { women with } \\
\text { chlamydial infection } \\
\text { only at insertion }\end{array}$ & $\begin{array}{l}\text { Women with cervical } \\
\text { infections at insertion: } \\
\text { RR for PID among } \\
\text { women with cervical } \\
\text { infections vs. women } \\
\text { with no cervical } \\
\text { infections (not including } \\
\text { women who had both } \\
\text { chlamydial infection } \\
\text { and gonorrhea): } \\
\text { - Placebo only: } \\
\text { 3/27 women with } \\
\text { gonorrhea had PID; } \\
\text { 2/90 women with } \\
\text { chlamydial infection } \\
\text { had PID } \\
\text { - Combined (placebo } \\
\text { and doxycycline): } \\
\text { 3/46 women with } \\
\text { gonorrhea had PID; } \\
\text { 4/186 women with } \\
\text { chlamydial infection } \\
\text { had PID } \\
\text { Women with no cervical } \\
\text { infection at insertion: } \\
\text { - Placebo only: } \\
\text { 9/670 had PID } \\
\text { - Combined (placebo } \\
\text { and doxycycline): } \\
\text { 15/1339 had PID }\end{array}$ & $\begin{array}{l}\text { - Short } \\
\text { follow-up } \\
\text { (1 month) }\end{array}$ & Low \\
\hline $\begin{array}{l}\text { Pap-Akeson, } \\
\text { et al., } 1992 \\
\text { [8], support } \\
\text { not stated }\end{array}$ & $\begin{array}{l}\text { To study the influence of the } \\
\text { position of the treads of an } \\
\text { intrauterine contraceptive } \\
\text { device on the development of } \\
\text { genital tract infection }\end{array}$ & $\begin{array}{l}\text { RCT }-2 \text { years; } \\
\text { Sweden } \\
\text { - IUD was either } \\
\text { inserted with } \\
\text { threads up or } \\
\text { threads down }\end{array}$ & $\begin{array}{l}445 \text { prospective } \\
\text { IUD users: } 208 \\
\text { threads up, } 237 \text { in } \\
\text { the threads-down } \\
\text { position }\end{array}$ & $\begin{array}{l}\text { Salpingitis: } \\
\text { diagnostic criteria } \\
\text { not stated } \\
\text { Endometritis: } \\
\text { diagnostic criteria } \\
\text { not stated }\end{array}$ & $\begin{array}{l}\text { - Women with signs } \\
\text { and symptoms of } \\
\text { genital infection and } \\
\text { irregular bleeding and } \\
\text { history of salpingitis } \\
\text { were excluded } \\
\text { - Samples were taken } \\
\text { before insertion, but } \\
\text { results were obtained } \\
\text { after insertion } \\
\text { Screening results: }\end{array}$ & $\begin{array}{l}\text { Women with cervical } \\
\text { infection at insertion: } \\
\text { - All } 13 \text { women were } \\
\text { treated with tetracyclines } \\
\text { with the IUD still in } \\
\text { place and had no } \\
\text { complications or } \\
\text { symptoms for } 2 \text { years } \\
\text { (although not all women } \\
\text { were followed up for } \\
\text { that time) }\end{array}$ & $\begin{array}{l}\text { - Did not } \\
\text { specify the } \\
\text { diagnostic } \\
\text { criteria for } \\
\text { salpingitis or } \\
\text { endometritis } \\
\text { - Did not } \\
\text { specify when } \\
\text { women were } \\
\text { given } \\
\text { antibiotic }\end{array}$ & Very low \\
\hline
\end{tabular}


Walsh et al.,

NICHD, NIH

To determine whether an

antibiotic before insertion ca

reduce premature IUD

Double-blind RCT

removal for medical reasons

3 months;

(including PID)
- 13/445 (2.9\%) had asymptomatic

chlamydial infection at insertion (no difference between the groups)

Skjeldestad, et al., 1996 [7],

Norwegian

Council for

Research
To evaluate screening for chlamydial infection at IUD insertion and its possible

effect on cause-related

terminations during the first

90 days after insertion

\section{Prospective study \\ 957 prospectiv \\ - No information of}

for 90 days;

Norway 1993-1995

IUD users

PID: diagnostic
criteria not stated

screening based on

signs or symptoms of

genital infection

- Samples were taken

prior to insertion, but

results were obtained

after insertion

Screening results:

- Chlamydial infection

in $5 / 957(0.5 \%)$ women

at insertion
Women with no cervical

infection at insertion

- $3 / 432(0.7 \%)$ women

with salpingitis and

$6 / 432(1.4 \%)$ with

endometritis (total:

$9 / 432,2.1 \%$ ), with the

threads-down group

having more upper

enital tract infections

Women with cervical

infection at insertion:

-6 women with

chlamydial infection

had no signs or

symptoms during

the study

- Woman with

gonorrhea had

IUD removed

Women with no cervical

infection at insertion:

$-1 / 201$ in the antibiotic group and $1 / 200$ in the

placebo group were

found to have PID

(combining both groups

PID 2/394, 0.05\%)

Women with cervical

infection at insertion:

$-1 / 5(20 \%)$

experienced a partial

IUD expulsion after

9 days; she was given

antibiotic treatmen

$-4 / 5(80 \%)$ did not

report any complications,

received antibiotic

treatment and did not

have any complications

up to day 90 (the end of

the study)

Women with no cervica

infection at insertion:

- None of the women had PID (0/952)

reatment

after

discovery of

chlamydial

infection

- Unclear if

en with

STIs at

were treated

- STI

screening

information

is only

available for

272 women

(61\%) of the

total IUD

prospective

- PID:

diagnostic

criteria not

stated

Very Low 


\begin{tabular}{|c|c|c|c|c|c|c|c|c|}
\hline Author, year, support & Objective & Study Design & Population & $\begin{array}{l}\text { Outcome (and } \\
\text { assessment) }\end{array}$ & Screening & Results & Weaknesses & Quality \\
\hline $\begin{array}{l}\text { Faúndes et al., } \\
1998 \text { [4], } \\
\text { Population } \\
\text { Council, } \\
\text { MacArthur } \\
\text { Foundation and } \\
\text { UNDP/UNFPA/ } \\
\text { WHO/WB }\end{array}$ & $\begin{array}{l}\text { To objectively evaluate how } \\
\text { effective the use of } \\
\text { sociodemographic factors, } \\
\text { sexual behavior and signs and } \\
\text { symptoms are in the } \\
\text { identification of women at } \\
\text { high risk for STIs among new } \\
\text { contraceptive acceptors }\end{array}$ & $\begin{array}{l}\text { Prospective study } \\
\text { for } 1 \text { month; Brazil } \\
\text { 1991-1992; Copper } \\
\text { T 380A }\end{array}$ & $\begin{array}{l}407 \text { prospective } \\
\text { IUD users; } \\
327 \text { actually } \\
\text { given IUD }\end{array}$ & $\begin{array}{l}\text { PID: criteria for } \\
\text { diagnosis not } \\
\text { stated; removal } \\
\text { due to PID }\end{array}$ & $\begin{array}{l}\text { - Women with history } \\
\text { of multiple partners, } \\
\text { purulent cervical } \\
\text { secretion, hyperemia } \\
\text { and bleeding of the } \\
\text { cervix at touch or } \\
\text { pelvic pain during } \\
\text { bimanual vaginal exam } \\
\text { were given a clinical } \\
\text { diagnosis of chlamydial } \\
\text { infection or gonorrhea } \\
\text { and were not given IUDs } \\
\text { - Samples were taken } \\
\text { before insertion, but } \\
\text { results were obtained } \\
\text { after insertion } \\
\text { Screening results: } \\
-19 / 327 \text { (5.8\%) had } \\
\text { chlamydial infection at } \\
\text { insertion of the IUD }\end{array}$ & $\begin{array}{l}\text { Women with cervical } \\
\text { infections at insertion: } \\
-2 / 19(10.5 \%) \text { complained } \\
\text { of lower abdominal pain } \\
2 \text { weeks after insertion } \\
-1 \text { woman }(1 / 19,5.26 \%) \\
\text { was diagnosed with PID, } \\
\text { fever and spontaneous } \\
\text { pelvic pain. IUD was } \\
\text { removed- } 1 \text { woman had } \\
\text { mild pain, but no fever } \\
\text { (the IUD was kept) } \\
\text { - The other } 17 \text { women did } \\
\text { not complain of any } \\
\text { symptoms but were given } \\
\text { doxycycline at their } \\
1 \text {-month visit } \\
\text { Women with no cervical } \\
\text { infections at insertion: } \\
\text { - No cases of PID in } \\
\text { acceptors with no cervical } \\
\text { infections (0/308) }\end{array}$ & $\begin{array}{l}- \text { No } \\
\text { information } \\
\text { about PID } \\
\text { diagnostic } \\
\text { criteria } \\
\text { - Short } \\
\text { follow-up } \\
\text { (1 month) }\end{array}$ & Very low \\
\hline $\begin{array}{l}\text { Morrison et al., } \\
1999 \text { [5], } \\
\text { support not } \\
\text { stated }\end{array}$ & $\begin{array}{l}\text { To evaluate the use of risk } \\
\text { assessment algorithms to } \\
\text { predict STI and subsequent } \\
\text { IUD-related complications } \\
\text { among IUD candidates }\end{array}$ & $\begin{array}{l}\text { Prospective study } \\
\text { (4 months with a } \\
\text { 1-month follow-up } \\
\text { visit); Kenya } \\
\text { 1994-1995; Copper } \\
\text { T 380A }\end{array}$ & $\begin{array}{l}\text { - } 649 \text { prospective } \\
\text { IUD users, } 615 \text { in } \\
\text { analysis (including } \\
144 \text { HIV-positive } \\
\text { women and } 471 \\
\text { HIV-negative } \\
\text { women) } \\
-580 \text { had tests for } \\
\text { cervical infections } \\
\text { (either a positive } \\
\text { chlamydial infection } \\
\text { test or gonorrhea } \\
\text { culture at the } \\
\text { 1-month follow-up } \\
\text { visit) }\end{array}$ & $\begin{array}{l}\text { PID: defined by } \\
\text { the United States } \\
\text { Infectious Disease } \\
\text { Society of } \\
\text { Obstetrics and } \\
\text { Gynecology }\end{array}$ & $\begin{array}{l}\text { - Women with active } \\
\text { PID, mucopurulent } \\
\text { cervical discharge or } \\
\text { high risk for STIs were } \\
\text { excluded from the study } \\
\text { - Samples were taken at } \\
1 \text { month after insertion } \\
\text { Screening results: } \\
\text { - } 32 / 580 \text { ( } 5.5 \% \text { ) women } \\
\text { had chlamydial infection } \\
\text { or gonorrhea at } 1 \text { month } \\
\text { of insertion. Eleven of } \\
\text { these women had HIV } \\
\text { and } 21 \text { of these women } \\
\text { did not have HIV } \\
- \text { Women with HIV } \\
\text { were more likely to } \\
\text { have infections than } \\
\text { noninfected women, } \\
\text { though this was not } \\
\text { statistically significant } \\
\text { ( } 7.8 \% \text { vs. } 4.8 \% \text {, p=.17) }\end{array}$ & $\begin{array}{l}\text { Women with cervical } \\
\text { infections at } 1 \text { month: } \\
-6 / 32(18.8 \%) \text { had } \\
\text { complications with the IUD } \\
-1 / 32(3.1 \%) \text { was } \\
\text { diagnosed with PID } \\
\text { (this woman did not } \\
\text { have HIV) } \\
\text { Women with no cervical } \\
\text { infections at } 1 \text { month: } \\
-25 / 548(4.6 \%) \\
\text { complications with IUD } \\
-2 / 548(0.4 \%) \text { women } \\
\text { had PID }\end{array}$ & $\begin{array}{l}\text { - Do not } \\
\text { know if } \\
\text { women had } \\
\text { chlamydial } \\
\text { infection or } \\
\text { gonorrhea at } \\
\text { the time of } \\
\text { insertion; } \\
\text { available } \\
\text { information } \\
\text { is for the } \\
\text { first month } \\
\text { follow-up }\end{array}$ & Very low \\
\hline
\end{tabular}


either before or after insertion [9]; and in one, testing for STIs was done at the first month follow-up visit [5]. In that study, it was assumed that because study participants were at low risk of developing STIs, the majority of women who tested positive (32 women) most likely acquired infection before the IUD was inserted (Morrison CS, FHI, June 4, 2003). Follow-up from the time of IUD insertion ranged from 1 month to 2 years.

As shown in Table 1 and Fig. 1, the prevalence of STIs and incidence of PID were low in all studies, producing wide variability in the confidence intervals. Rates of diagnosed PID ranged from $0 \%$ to $5 \%$ among women with STIs at IUD insertion and $0 \%$ to $2 \%$ for those without STIs at IUD insertion. One of the studies, however, also identified a possible case in a woman with STI at insertion (the woman had lower abdominal pain but no fever); if this case is included, the upper boundary of PID among those with STI would be $10.5 \%$ [4]. With the exception of the study of Skjeldestad et al. [7] that observed no cases of PID in the study population, all of the studies observed a greater risk of PID among women with STIs (combining gonorrhea and chlamydial infection) at IUD insertion than women with no STI at insertion, with crude relative risks ranging from 1.63 to 46.35 . The Sinei et al. [6] study, which had the largest sample size of the studies and a high follow-up rate, yielded a relative risk of 2.69 (95\% CI 1.11-6.53). Fig. 2 shows results for chlamydial infection and gonorrhea separately and also suggests a trend of greater risk of PID with infection, although the number of cases was quite low, leading to imprecise estimates.

\section{Discussion}

There are theoretical concerns that, among women with current STIs, the process of inserting an IUD and perhaps the presence of the device may facilitate the ascendance of sexually transmitted organisms from the lower to the upper genital tract. This review found no studies that were able to examine appropriate case and comparison groups to assess this question and, correspondingly, to determine whether among women with STIs the insertion and use of an IUD increases the risk of PID. Of six studies that provided indirect evidence, current STI at the time of IUD insertion increased the risk of PID, albeit only two of the increases were statistically significant [4-9]. This finding is expected, as gonorrhea and chlamydial infection are the major etiologic agents for PID in women who do not use the IUD. We do not know, however, whether this increase in risk is the same or greater than the risk for PID among women who do not undergo IUD insertion. We do know that the absolute risk of PID remained low among women who had an STI when their IUD was inserted, in the range of $0-5 \%$ (or possibly as high as $11 \%$, if the "possible" case of PID was included).

Unfortunately, the overall quality of the indirect studies was "very low." The studies varied in the level of initial screening for STIs and their diagnostic criteria for PID, thereby possibly introducing selection and misclassification bias. Because of the limited number of women with STIs and PID in these studies, assessing possible confounders was not possible. The main limitation of this body of indirect evidence was the small number of cases, which is explained by the current practice of screening for STIs before inserting an IUD and the low prevalence of STIs and incidence of PID in populations desiring IUD insertion.

Ideally, we would like to have evidence from studies that examined the following question: among women with STIs, does insertion of an IUD increase the risk of PID compared with no IUD insertion? Ethically, this study would be difficult to conduct, as women could not be followed, untreated, to assess their risk of developing PID. There is some evidence, however, regarding the risk of PID among women with STIs in the general population who are not IUD users. A study of 129 women with both cervical chlamydial infection and gonorrhea who were treated with penicillin (which does not affect chlamydial infection) found that 9\% (11/129) subsequently developed PID [12]. Another study that also treated women having both gonorrhea and chlamydial infection with penicillin found that 30\% (6/20) developed PID [13]. Finally, a study of 19 women with gonorrhea found that nine of the women developed PID (four had adenexal tenderness), a median of 11 days after diagnosis of cervical infection [14]. When the risk of developing clinical PID attributable to an IUD was calculated using a model derived from existing studies, the risk was $0.15 \%$ when the prevalence of the gonorrhea and chlamydial infection in the population was approximately $10 \%$, and there was screening for genital infections [15].

Some still argue that the use of an IUD increases the risk of PID regardless of whether STIs are present. Indeed, a meta-analysis that identified 36 papers published between 1974 and 1990 concluded that there was a positive association between IUD use and PID, even in subgroups examining IUDs that were not Dalkon Shields, and when separating symptomatic and asymptomatic PID [16]. There are several biases inherent in observational studies of this question [3,17], however, which cannot be resolved through meta-analysis. First, it is difficult to identify a valid control group with which to compare IUD users - the use of hormonal methods, barrier methods or sterilization decreases risk of PID, and women who do not use contraceptives may be very different from users with regard to age, parity and sexual risk behaviors. Second, a detection bias may be at work, as IUD users may be more likely to be diagnosed (or overdiagnosed) with PID. Third, many studies have not adequately controlled for potential confounding factors, primarily sexual behavior. Therefore, it remains difficult to answer this question with observational study designs.

Even without valid relative risks, absolute rates of PID among IUD users are reported to be low. In a 5-year follow- 
up study in eight developing countries, the rate of acute PID among users of the copper IUD was 0.6 per 1000 womanyears [18]. In randomized controlled trials of prophylactic use of antibiotics at IUD insertion, PID among the placebo group with IUD insertion has been rare, even in populations with high background prevalence of STIs-1.11\% in Nigeria at 30 days after insertion [19] and 1.9\% in Kenya at 1 month after insertion [6].

In summary, the study findings consistently showed that women with STIs have a greater risk of PID than women with no STIs when an IUD is inserted, but the absolute risk of PID among women with STIs at the time of IUD insertion is low. We have no information to determine whether the risk of PID among women with STIs who do not receive an IUD is of the same magnitude. Therefore, whether IUDs increase the risk of PID in women with STI at the time of insertion is not known.

In 2003, the WHO Expert Working Group reviewed this evidence to evaluate current medical eligibility criteria for use of copper and levonorgestrel-releasing IUDs [20]. The Expert Working Group recommended that women with current purulent cervicitis or cervical chlamydial infection or gonorrhea should not have an IUD inserted (WHO Category 4), but women who already have an IUD in place and are found to have a cervical infection can generally continue use of the copper or levonorgestrel-releasing IUD (WHO Category 2). Women with other STIs (excluding women with hepatitis desiring the levonorgestrel-releasing IUD, because of concerns regarding hormonal effects on the course of disease) and women with vaginitis can generally initiate and continue use of copper or levonorgestrelreleasing IUDs (WHO Category 2).

\section{Acknowledgments}

This review was supported by resources from the World Health Organization, the US Centers for Disease Control and Prevention (CDC), US Agency for International Development (USAID) and the US National Institute of Child Health and Human Development (NICHD). We would also like to acknowledge the assistance of William Thomas, MLIS, Technical Information Specialist at CDC, in developing the literature search strategies.

The findings and conclusions in this report are those of the author(s) and do not necessarily represent the views of the funding agencies.

\section{Appendix A. Study quality assessment}

\section{A.1. Individual study}

Each study was given a rating of very low, low, intermediate or high based on the interval validity of the study. If the study was indirect, the quality of the individual study was lowered by one level. If the study was direct, the quality of evidence was kept the same. Similarly, if there was sparseness of the data, the quality of the individual study was lowered by one level.

\section{A.2. Body of evidence}

The quality of the body of evidence was the highest rating given to an individual study. If the results were inconsistent, the quality of the body of the evidence was lowered by one level. If results were consistent, then the quality of the body of the evidence was left at the original level. Similarly, if there was reporting bias (publication bias), then the quality of the body of evidence would be lowered by one level.

Quality of evidence across studies for each main outcome

\begin{tabular}{ll}
\hline RCT & $\begin{array}{l}\text { Quality of } \\
\text { the evidence }\end{array}$ \\
& studies
\end{tabular}

\begin{tabular}{|c|c|c|}
\hline $\begin{array}{l}\text { No serious flaws in } \\
\text { study quality }\end{array}$ & High & $\begin{array}{l}\text { Extremely strong } \\
\text { association and } \\
\text { no threats to } \\
\text { validity }\end{array}$ \\
\hline $\begin{array}{l}\text { Serious flaws in } \\
\text { design or execution } \\
\text { or quasi-experimental } \\
\text { design }\end{array}$ & Intermediate & $\begin{array}{l}\text { Strong, consisten } \\
\text { association and } \\
\text { no plausible } \\
\text { confounders }\end{array}$ \\
\hline $\begin{array}{l}\text { Very serious flaws in } \\
\text { design or execution }\end{array}$ & Low & $\begin{array}{l}\text { No serious flaws } \\
\text { in study quality }\end{array}$ \\
\hline $\begin{array}{l}\text { Very serious flaws and } \\
\text { at least one other } \\
\text { serious threat to validity }\end{array}$ & Very low & $\begin{array}{l}\text { Serious flaws in } \\
\text { design and } \\
\text { execution }\end{array}$ \\
\hline
\end{tabular}

Additional factors that lower study quality are as follows: important inconsistency of results; some uncertainty about directness; high probability of reporting bias; and sparseness of data. Major uncertainty about directness can lower the quality by two levels.

Additional factors that may increase quality of observational studies are as follows: all plausible residual confounding, if present, would reduce the observed effect, and evidence of a dose-response gradient.

Adapted from: Judging Confidence: Guidelines for Grading Evidence and Recommendations. Grades of Recommendation Assessment, Development, and Evaluation (GRADE) Working Group. Draft, January 2003.

\section{References}

[1] UNDP/UNFPA/WHO/World Bank Special Programme of Research, Development and Research Training in Human Reproduction. A plethora of IUDs: but how safe, how effective? Prog Reprod Health Res 2002;60:3.

[2] Westrom L, Eschenbach D. Pelvic inflammatory disease. In: Holmes K, Sparling P, Mardh P, et al, editors. Sexually transmitted diseases. 3rd ed. New York: McGraw-Hill; 1999. p. 783-809.

[3] Grimes DA. Intrauterine device and upper-genital-tract infection. Lancet 2000;356:1013-9.

[4] Faúndes A, Telles E, Cristofoletti ML, Faúndes D, Castro S, Hardy E. The risk of inadvertent intrauterine device insertion in women carriers of endocervical Chlamydia trachomatis. Contraception 1998; 58:105-9. 
[5] Morrison CS, Sekadde-Kigondu C, Miller WC, Weiner DH, Sinei SK Use of sexually transmitted disease risk assessment algorithms for selection of intrauterine device candidates. Contraception 1999;59: 97-106.

[6] Sinei SK, Schulz KF, Lamptey PR, et al. Preventing IUCD-related pelvic infection: the efficacy of prophylactic doxycycline at insertion. Br J Obstet Gynaecol 1990;97:412-9.

[7] Skjeldestad FE, Halvorsen LE, Kahn H, Nordbo SA, Saake K. IUD users in Norway are at low risk for genital C. trachomatis infection. Contraception 1996;54:209-12.

[8] Pap-Akeson M, Solheim F, Thorbert G, Akerlund M. Genital tract infections associated with the intrauterine contraceptive device can be reduced by inserting the threads into the uterine cavity. Br J Obstet Gynaecol 1992;99:676-9.

[9] Walsh TL, Bernstein GS, Grimes DA, et al. Effect of prophylactic antibiotics on morbidity associated with IUD insertion: results of a pilot randomized controlled trial. Contraception 1994;50:319-27.

[10] Mohllajee AP, Curtis KM, Flanagan RG, Rinehart W, Gaffield ML, Peterson HB. Keeping up with evidence: a new system for WHO's evidence-based family planning guidance. Am J Prev Med 2005;28: 483-90.

[11] Grades of Recommendations, Assessment, Development, and Evaluation (GRADE) Working Group. Grading quality of evidence and strength of recommendations. BMJ 2004;328:1490-4.
[12] Rees E. The treatment of pelvic inflammatory disease. Am J Obstet Gynecol 1980;138:1042-7.

[13] Stamm WE, Guinan ME, Johnson C, Starcher T, Holmes KK, McCormack WM. Effect of treatment regimens for Neisseria gonorrhoeae on simultaneous infection with Chlamydia trachomatis. N Engl J Med 1984;310:545-9.

[14] Platt R, Rice PA, McCormack WM. Risk of acquiring gonorrhea and prevalence of abnormal adnexal findings among women recently exposed to gonorrhea. JAMA 1983;250:3205-9.

[15] Shelton JD. Risk of clinical pelvic inflammatory disease attributable to an intrauterine device. Lancet 2001;357:443.

[16] Gareen IF. Intrauterine devices and pelvic inflammatory disease. Curr Women's Health Rep 2003;3:280-7.

[17] Kessel E. Pelvic inflammatory disease with intrauterine device use: a reassessment. Fertil Steril 1989;51:1-11.

[18] International Collaborative Post-Marketing Surveillance of Norplant. Post-marketing surveillance of Norplant contraceptive implants: I. Contraceptive efficacy and reproductive health. Contraception 2001; 63:167-86.

[19] Ladipo OA, Farr G, Otolorin E, et al. Prevention of IUD-related pelvic infection: the efficacy of prophylactic doxycycline at IUD insertion. Adv Contracep 1991;7:43-54.

[20] WHO. Medical eligibility criteria for contraceptive use. 3rd ed. Geneva: World Health Organization; 2004. 